https://doi.org/10.18778/7525-969-8.33

Matgorzata Eakota-Micker

\title{
Republika Chorwacji - 28. państwo członkowskie Unii Europejskiej
}

Republika Chorwacji to państwo, które zgodnie z przyjętym harmonogramem, dnia 1 lipca 2013 r. dołączy do grona 27 państw członkowskich Unii Europejskiej (UE). Pomyślnie zakończone negocjacje akcesyjne i pozytywny wynik uzyskany w trakcie referendum są potwierdzeniem, że na akcesji zależy zarówno władzom państwa, jak i jego obywatelom. Członkostwo w Unii Europejskiej to dla Zagrzebia kolejny, po uregulowaniu stosunków w regionie i przystapieniu do NATO, znaczący sukces. To wypełnienie trzeciego z priorytetowych założeń, przyjętych w polityce zagranicznej państwa, określonych w chwili proklamacji przez nie niepodległości, tj. 25 czerwca 1991 r. (pełna niepodległość ogłoszona została 8 października, gdy parlament zerwał wszelkie konstytucyjne powiązania $\mathrm{z}$ federacją jugosłowiańska).

Przebieg procesu zjednywania sobie przez Chorwację zaufania wśród państw - sąsiadów można określić jako udany. Chorwacja nie ma otwartych kwestii spornych, a wszelkie niewyjaśnione do końca sprawy, mające swoje korzenie jeszcze w latach 90. XX w. i stanowiące następstwo rozpadu byłej Socjalistycznej Federacyjnej Republiki Jugosławii, stara się rozwiązywać polubownie ${ }^{1}$. W ciagu minionych lat Republika Chorwacji dała się poznać jako państwo zaangażowane i aktywnie działające na rzecz wypełniania zobowiązań zaciagniętych wobec największych międzynarodowych organizacji. Dnia 1 kwietnia 2009 r. została oficjalnie przyjęta do NATO. Członkostwo w tej polityczno-wojskowej organizacji stało się potwierdzeniem jej demokratycznego ustroju i gotowości wypełniania kryteriów politycznych, gospodarczych i ekonomicznych. Dla stosunkowo niewielkiego państwa, o powierzchni 87609 km², zamieszkałego przez 4437460 mieszkańców ${ }^{2}$, przynależność do Sojuszu Północnoatlantyckiego to nie tylko gwarancja bezpieczeństwa, wynikająca $\mathrm{z}$ art. 5 traktatu waszyngtońskiego, ale i swego

${ }^{1}$ Dla przykładu sprawa tocząca się między Słowenią a Chorwacją o aktywa zdeponowane w Ljubljanskim Banku.

2 Ambasada Republiki Chorwacji w Polsce, Dane podstawowe, pl.mfa.hr (dostęp 22 II 2012). 
rodzaju przepustka do członkostwa w $\mathrm{UE}^{3}$. Cztery swobody wolnego rynku (swobodny przepływ osób, usług, kapitału, towarów) gwarantowane przez traktat o Unii Europejskiej i możliwość funkcjonowania wśród najbardziej rozwiniętych gospodarczo krajów, dla Chorwacji, zmagającej się z recesją (od 2009 r.) i mającej dług publiczny w wysokości $60 \%$ PKB oraz stopień bezrobocia na poziomie $17,9 \%$, to szansa na poprawę sytuacji ${ }^{4}$. To możliwość podniesienia stopnia zamożności i utrzymania pozycji lidera $\mathrm{w}$ regionie, bo tak jest postrzegana $\mathrm{w}$ odniesieniu do pozostałych byłych republik Jugosławii ${ }^{5}$. Członkostwo Chorwacji w UE, to wreszcie gwarancja dla partnerów gospodarczych z całego świata, potwierdzona unijnym znakiem dobra jakość towarów spełniajacych wymagane kryteria, ale i polepszenie infrastruktury państwowej, możliwość funkcjonowania bez granic, wspólnie z innymi narodami zjednoczonej Europy.

Wypełnianie kryteriów kopenhaskich ${ }^{6}$, takich jak stabilność instytucji demokratycznych, praworządność, poszanowanie praw człowieka, ochrona mniejszości narodowych, stworzenie funkcjonującej gospodarki rynkowej, gotowość sprostania warunkom konkurencji unijnej, zdolność do wypełniania obowiązków wynikających z członkostwa i przyjęcie dorobku prawnego Unii Europejskiej, potwierdziło gotowość Chorwacji do ubiegania się o członkostwo w Unii7. Swoistym wyznacznikiem ram dla proeuropejskiego kursu polityki Bałkanów Zachodnich, w tym Chorwacji, aż do momentu ich przyszłej akcesji, stał się Proces Stabilizacji i Stowarzyszenia - wspierający rozwój państw Europy

${ }^{3}$ Artykuł 5 traktatu północnoatlantyckiego mówi, że „Strony zgadzają się, że zbrojna napaść na jedną lub kilka z nich, w Europie lub Ameryce Północnej będzie uważana za napaść przeciwko nim wszystkim; wskutek tego zgadzają się one na to, że jeżeli taka zbrojna napaść nastapi, każda z nich, w wykonaniu prawa do indywidualnej lub zbiorowej samoobrony, uznanego przez art. 51 Karty Narodów Zjednoczonych, udzieli pomocy Stronie lub Stronom napadniętym, podejmując natychmiast indywidualnie i w porozumieniu z innymi Stronami taką akcję, jaką uzna za konieczna, nie wyłączając użycia siły zbrojnej, w celu przywrócenia i utrzymania bezpieczeństwa obszaru północnoatlantyckiego" - zob. Powstanie NATO, Kalendarium wydarzen, „Polska.pl”, http://www.kalendarium.polska.pl.

${ }^{4}$ J. Pawlicki, Chorwacja: $z$ Jugostawii do Unii w 21 lat, „Gazeta Wyborcza”, 23 I 2012 , s. 11.

${ }^{5}$ Wyjątek stanowi tu Słowenia.

${ }^{6}$ Kryteria kopenhaskie zostały ustalone na szczycie Rady Europejskiej w Kopenhadze, w dniach 21-22 czerwca 1993 r. To kryteria stawiane państwom chcącym przyłączyć się do UE.

${ }^{7}$ Kryteria kopenhaskie stanowią dla Komisji Europejskiej potwierdzenie stanu przygotowania poszczególnego państwa do członkostwa. Opierając się na uzyskanych wynikach i analizach, Komisja formułuje tzw. avis, opinię dotyczącą zdolności kraju kandydującego do sprostania roli członka Unii Europejskiej. Avis jest również podstawą do rozpoczęcia negocjacji między Unią a danym krajem. Urząd Komitetu Integracji Europejskiej, http://www. cie.gov.pl/WWW/quest.nsf/0/E94FF12B879ADE4EC1256E860027B9BD?open. 
Południowo-Wschodniej. Miał on za zadanie stworzyć podstawy ich przyszłego członkostwa w Unii Europejskiej dzięki połączeniu trzech typów instrumentów: Układów o Stabilizacji i Stowarzyszeniu, autonomicznych środków handlowych i wsparciu finansowemu ${ }^{8}$. Rozmowy na temat porozumienia rozpoczęto przy okazji szczytu w Zagrzebiu 24 listopada $2000 \mathrm{r}$. Był on pierwszym oficjalnym wydarzeniem $\mathrm{w}$ historii kontaktów pomiędzy przedstawicielami UE i delegacjami demokratycznych państw Bałkanów Zachodnich. Od tego momentu można mówić o faktycznym rozpoczęciu procesu integracji w Południowo-Wschodniej części Europy. W Zagrzebiu, po raz pierwszy, doszło wówczas do oficjalnego spotkania przedstawicieli 15 państw i rządów - członków Unii Europejskiej oraz przedstawicieli państw objętych Procesem Stabilizacji i Stowarzyszenia, pozostających poza obszarem Unii ${ }^{9}$. Końcowa deklaracja ze spotkania stała się punktem zwrotnym dla rozwoju politycznych i gospodarczych stosunków pomiędzy stronami. Zagwarantowana została nią europejska perspektywa dla wszystkich państw objętych Programem Partnerstwa, przy poszanowaniu indywidualnych osiagnięć każdego z nich. Poparto i doceniono regionalną współpracę. Obiecano aktywnie wspierać wysiłki państw zmierzających w kierunku demokracji, rządów prawa, pojednania i współpracy opartej na poszanowaniu istniejących granic i międzynarodowych zobowiązań, które przyczynią się do zbliżenia pomiędzy każdym z państw a Unia.

Chorwacja podpisała Układ o Stabilizacji i Stowarzyszeniu 29 października 2001 r., tym samym czyniąc znaczący postęp w sferze instytucjonalizacji stosunków z UE. Tymczasowe Porozumienie odnoszące się do problematyki handlowej i transportu weszło w życie 1 stycznia 2002 r. Chorwacki Sabor zaakceptował Układ o Stabilizacji i Stowarzyszeniu 5 grudnia 2001 r., a 12 grudnia 2001 r. to samo uczynił Parlament Europejski. Rada Ministrów Unii Europejskiej 28 stycznia 2002 r. potwierdziła Tymczasowe Porozumienie tak, by Chorwacja mogła bez problemów i opóźnień przyłączyć się do harmonogramu handlowego UE. Układ, jako kluczowy element unijnego Procesu Stabilizacji i Stowarzyszenia ostatecznie wszedł w życie 1 lutego $2005 \mathrm{rr}^{10}$

Z oficjalnym wnioskiem o członkostwo w Unii Europejskiej Republika Chorwacji wystapiła w Atenach 21 lutego $2003 \mathrm{r} .{ }^{11}$ Za jego przygotowanie odpowiedzialność ponosiła „grupa robocza” powołana w 2002 r. przez chorwacki rząd.

8 Proces Stabilizacji i Stowarzyszenia, Komisja Europejska, http://ec.europa.eu/enlargement/enlargement_process/accession_process/how_does_a_country_join_the_eu/sap/ index_pl.htm.

${ }^{9}$ L. Čehulić, Croatia on the Path to European Union, „Yearbook Šipan 2005”, Zagreb 2006, s. 47.

${ }^{10}$ Chorwacja, Rozszerzenie, Komisja Europejska, http://ec.europa.eu/enlargement/ candidate-countries/croatia/relation/index_pl.htm (dostęp 23 II 2011).

${ }^{11}$ Hrvatska na putu u Europsku Uniju, od kandidature do članstva, 3 izd., Zagreb 2006, s. 35. 
W jej skład weszli przedstawiciele: prezydenta, Saboru, rządu Republiki Chorwacji, Ministerstwa Spraw Zagranicznych i Ministerstwa Integracji Europejskiej $^{12}$. Zadaniem grupy była koordynacja działań, począwszy od przygotowania samego tekstu wniosku, na przedsięwzięciach związanych z wypełnianiem jego złożeń kończąc.

Dnia 14 kwietnia 2003 r. Rada Unii Europejskiej zadecydowała o rozpoczęciu postępowań przewidzianych art. 49 traktatu o UE. Zwróciła się do Komisji Europejskiej o przygotowanie opinii (avis) ${ }^{13}$, dotyczącej wniosku Republiki Chorwacji o członkostwie w Unii. Za konieczne ze strony Chorwacji uznano wówczas podjęcie działań na rzecz walki z korupcja, ochrony praw mniejszości narodowych, przeprowadzenie reformy sądownictwa czy zintensyfikowanie współpracy z Międzynarodowym Trybunałem Karnym dla byłej Jugosławii (ICTY). W czerwcu 2003 r. chorwackie władze otrzymały od Komisji Europejskiej kwestionariusz, który - wypełniony - zwrócono stronie unijnej 9 października tego samego roku ${ }^{14}$. Udzielone na 4560 pytań odpowiedzi opisywały sytuację panującą w państwie. W następstwie pozytywnie zaliczonego etapu, 20 kwietnia 2004 r., Komisja Europejska opublikowała avis, w sprawie chorwackiego wniosku o członkostwo w $\mathrm{UE}^{15}$. W części poświęconej kryteriom politycznym, Chorwacja została uznana za państwo demokratyczne, z właściwie funkcjonującymi instytucjami państwowymi, przestrzegające zasad współpracy i podziału kompetencji1 ${ }^{16}$. Zwrócono uwagę na zmiany, jakie dokonały się od 2000 r., obejmujące m.in. poprawki w konstytucji - wzmocnienie pozycji parlamentu, przestrzeganie zasad demokracji i praworządności przy przeprowadzaniu wyborów oraz gwarancje aktywnego udziału opozycji w życiu politycznym. Odnotowano rozpoczęcie reformy w chorwackiej armii i policji. Komisja odniosła się z uznaniem do działań podjętych przez premiera Ivo Sana-

12 W skład „grupy roboczej” wchodzili: przewodniczący (2): minister spraw zagranicznych i minister integracji europejskiej; członkowie - przedstawiciele (14): z Ministerstwa Spraw Zagranicznych (6), Ministerstwa Integracji Europejskiej (5), urzędu prezydenta (1), urzędu premiera (1), Komitetu Integracji Europejskiej Saboru (1).

${ }^{13}$ Hrvatska na putu u..., s. 41.

${ }^{14}$ Warto zwrócić uwagę na fakt, że strona chorwacka w dość szybkim tempie udzieliła odpowiedzi na kwestionariusz. Stało się tak z tego względu, że prace nad odpowiedziami rozpoczęto znacznie wcześniej, wzorując się na dokumencie sąsiedniej Słowenii.

15 Wniosek powyższy został złożony w lutym 2003 r. Zawierał analizę sytuacji politycznej i ekonomicznej Chorwacji pod kątem stopnia wypełniania kryteriów na rzecz członkostwa, które sformułowane zostały przez Radę Europejską w Kopenhadze w czerwcu 1993 r. i zostały przyjęte w założeniach Procesu Stabilizacji i Stowarzyszenia w kwietniu 1997 r. M. Sošić, Hrvatska strategija europskih integracija 2000-2005., „Anali Hrvatskog politološkog društva” 2006, br. 1, s. 155 .

16 A. Brnčić, P. Leppee, I. Mošnja, Croatia on the Road to European Union: From Candidacy to Membership, Zagreb 2004, s. 44. 
dera i jego rząd, powołany po wyborach w 2003 r. ${ }^{17}$ Za największe problemy, wymagające zaangażowania ze strony władz lokalnych i rządu, w dokumencie uznano: konieczność przeprowadzenia reformy sądownictwa (dającej gwarancję odpowiedniego przygotowania merytorycznego kadr znających prawo unijne, języki obce, odpowiednio wyposażonych sądów, zapewnienia ich właściwej infrastruktury i odpowiednich rozwiązań organizacyjnych), podjęcie działań na rzecz polepszenia sytuacji mniejszości etnicznych (dostęp do szkolnictwa, możliwość ubiegania się o zwrot majątku przejętego w trakcie wojny domowej w byłej Jugosławii, podpisania stosownych porozumień, gwarantujących prawa i obowiązki mniejszości). Odnosząc się do realizacji zadań ICTY, Komisja oparła się na ocenie, dokonanej przez prokurator Carlę Del Ponte. W wystawionej opinii, współpracę Chorwacji z Trybunałem uznała ona za pełna, jednak jednocześnie apelowała do władz w Zagrzebiu, by te dołożyły wszelkich starań, aby oskarżony, lecz wciąż pozostający na wolności, gen. Ante Gotovina stawił się w Hadze lub został przekazany Trybunałowi. Za istotne Komisja uznała uregulowanie przez Chorwację kwestii spornych w relacjach z państwami sąsiednimi (problem delimitacji i demarkacji granic z Serbią i Czarnogóra, spór z Bośnią i Hercegowiną o kontrolę nad portem Ploče, kwestia podwójnego obywatelstwa Chorwatów zamieszkałych w Bośni i Hercegowinie, spory ze Słowenią o strefę ekologiczną i rybołówstwa na wodach przybrzeżnych Adriatyku, tzw. ZERP czy funkcjonowanie elektrowni jądrowej Krško, a także sprawa rozdziału środków zdeponowanych przed $1991 \mathrm{r}$. w oddziałach Ljubljanska Banka). Zastrzeżenia Komisji wzbudziło także funkcjonowanie i poziom niezależności chorwackich mediów, głównie lokalnych. Podkreślono konieczność wzmocnienia administracji na szczeblu lokalnym i podjęcia energicznych działań w walce z korupcją. Przechodząc do kryteriów ekonomicznych, Komisja Europejska uznała, że w Chorwacji funkcjonuje gospodarka rynkowa, która w średnim okresie będzie w stanie sprostać konkurencji na rynku wspólnotowym i wypełniać wynikające z członkostwa w UE obowiązki, o ile władze zmierzą się z szeregiem niezbędnych w poszczególnych sektorach reform. Komisja Europejska, analizując rozdziały negocjacyjne i oceniając pod tym kątem stopień przygotowania Chorwacji do członkostwa w Unii Europejskiej, wiele uwagi poświęciła zgodności aktów prawa krajowego, regulujących podstawowe dziedziny z acquis. Ocena wskazywała, że większość ustaw zawierała zgodne z zasadniczymi regułami Unii postanowienia. Poprawek wymagały m.in. sprawy związane ze swobodnym przepływem osób, stawki i sposób naliczania podatku VAT i akcyzy, specjalne strefy ekonomiczne, pomoc państwa czy wsparcie dla poszczególnych segmentów rolnictwa. Zdaniem Komisji, niezbędne było wzmocnienie administracji

${ }_{17}$ Przemiany miały na celu realizację zaległych zobowiązań. Mowa tu m.in. o współpracy z ICTY, nawiązaniu dialogu z przedstawicielami mniejszości, poprawie warunków dla powracających uchodźców. 
i stworzenie bądź zmodyfikowanie struktur odpowiedzialnych za wdrażanie acquis, nadzorowanie funkcjonowania sektora, procesy standaryzacji, wydawanie certyfikatów oraz odpowiednie zarządzanie środkami pomocowymi. Przyśpieszenia wymagał proces prywatyzacji państwowych przedsiębiorstw, modernizacja rolnictwa, powiązana ze wspieraniem rozwoju obszarów wiejskich, modernizacja gałęzi przemysłu z uwzględnieniem głównie przemysłu stoczniowego, jak i potrzeba kontynuacji reform polityki fiskalnej oraz systemu zabezpieczenia społecznego. Komisja stwierdziła, że jedynie w dziedzinie ochrony środowiska Chorwacja będzie w stanie sprostać kryteriom członkostwa tylko w długim okresie, zakładając przy tym, że poczynione zostaną inwestycje oraz nastapi wzmocnienie zdolności administracji, odpowiedzialnej za proces implementacji aktów prawnych, regulujących tę dziedzinę. Pozostałe sektory oceniano pozytywnie. Zdaniem Komisji najmniej problemów przysporzyć miały: polityka gospodarcza i walutowa, statystyka, polityka przemysłowa, budżet i finanse, działania wobec małych i średnich przedsiębiorstw, nauka i badania, edukacja, kultura i polityka audiowizualna, stosunki zewnętrzne, wspólna polityka zagraniczna i bezpieczeństwa ${ }^{18}$.

Chorwacja otrzymała status państwa kandydata do pełnoprawnego członkostwa w UE 18 czerwca 2004 r. Podczas spotkania Rady Europejskiej, które odbywało się w dniach 17-18 czerwca 2004 r., dyskutowano nad poszerzeniem Unii o nowe państwa (Bułgarię, Rumunię, Turcję i Chorwację) ${ }^{19}$. Podkreślono, że Rada Europejska przyjęła opinię Komisji na temat chorwackiego wniosku o członkostwo i rekomenduje otwarcie rozmów z Republiką Chorwacji na temat przyszłego, pełnoprawnego członkostwa. Wskazywano, że wniosek o członkostwo poparty został pozytywną opinią Komisji Europejskiej, a strona chorwacka wypełnia stawiane jej przez Radę Europejską kryteria polityczne z Kopenhagi. Chorwacja wypełniła również warunki wynikające z Procesu Stabilizacji i Stowarzyszenia, które nakreślone zostały przez Radę w 1997 r.

Rozmowy o przystapieniu Republiki Chorwacji do Unii Europejskiej rozpoczęły się w Luksemburgu 4 października 2004 r. Doszło wówczas do pierwszego posiedzenia Międzyrządowej Konferencji, w której uczestniczyli przedstawiciele państw członkowskich UE i Chorwacji. Po podjęciu decyzji dotyczącej rozpoczęcia negocjacji z Chorwacja, kolejnym etapem w zbliżaniu tego państwa do Unii był tzw. proces screeningu. Poprzedzał on rekomendację Komisji Europejskiej w sprawie możliwości otwarcia negocjacji w poszczególnych rozdziałach. Zgodnie z dalszymi propozycjami, przed rozpoczęciem rozmów w każdym z obszarów, Komisja zobowiązywała się określić warunki umożliwiające zamknięcie danego obszaru. Postęp negocjacji uzależniony został od wywiązywania się Chorwacji

18 Patrz więcej: M. Łakota-Micker, Proces akcesji Republiki Chorwacji do Unii Europejskiej, Wrocław 2011, passim.

19 Council of the European Union, Brussels European Council 17 and 18 June 2004, Presidency conclusion, 10679/2/04 REV 2, CONCL 2, Brussels, 19 VII 2004. 
ze zobowiązań wynikających z postanowień Umowy o Stabilizacji i Stowarzyszeniu. Warunki o których mowa, dotyczyły zarówno stopnia dostosowania prawa krajowego do wymogów acquis communautaire, jak i postępów w procesie implementacji ${ }^{20}$. Dnia 17 grudnia $2004 \mathrm{r}$. Rada Europejska podała do wiadomości, że 16 marca 2005 r. oficjalnie rozpoczną się negocjacje akcesyjne z Republiką Chorwacji. Przeszkoda, która opóźniła jednak proces i w związku z którą poprzestano tylko na przyjęciu ram negocjacyjnych, był brak pełnej współpracy chorwackich władz z Trybunałem w Hadze. Dopiero jej usunięcie, potwierdzone przez prokurator ICTY Del Ponte sprawiło, że zapadła decyzja o formalnym rozpoczęciu negocjacji akcesyjnych. Rozpoczęto je 3 października 2005 r. ${ }^{21}$ Negocjacje akcesyjne objęły 35 rozdziałów.

Stanowiska negocjacyjne Unii Europejskiej i państwa kandydata omawiane były i negocjowane w trakcie posiedzeń Międzyrządowej Konferencji. W jej trakcie, bezpośrednio prowadzono na poziomie eksperckim między przedstawicielami Komisji Europejskiej a państwem kandydującym regularne konsultacje i rozmowy, mające na celu pomoc w ominięciu ewentualnych problemów. Po osiagnięciu porozumienia pomiędzy Unią Europejską a państwem kandydującym na temat danego obszaru, o ile wypełnione zostały wstępne warunki do jego zamknięcia, uważany był on za tymczasowo zamknięty. Formalną decyzję na ten temat przedstawiała Międzyrządowa Konferencja na poziomie ministerialnym.

W trakcie negocjacji majacych doprowadzić do pełnoprawnego członkostwa, Komisja Europejska nadzorowała postępy państwa kandydata. Zwracała uwagę na wypełnianie przez nie kryteriów na rzecz członkostwa oraz śledziła, które z nich Chorwacja przyjęła w poszczególnych obszarach negocjacyjnych. O postępach na bieżąco informowana była Rada Unii Europejskiej. Komisja Europejska przygotowywała cykliczne, roczne sprawozdania o postępie państwa kandydata w procesie akcesyjnym. $\mathrm{O}$ toku negocjacji regularnie powiadamiany był Parlament Europejski.

Chorwacja zobowiązana była w ramach negocjacji regularnie przedstawiać i dostarczać UE informacje o postępie w przyjmowaniu jej prawnego dorobku i umacnianiu możliwości administracyjnych ${ }^{22}$. W celu prawidłowego i sprawnego przeprowadzania negocjacji, rząd Republiki Chorwacji powołał odpowiednie ciała

${ }^{20}$ Opracowanie na podstawie Informacji na temat relacji Unii Europejskiej i państw regionu Bałkanów Zachodnich MSZ, materiały w posiadaniu autorki.

${ }^{21}$ Dokument określający ramy negocjacyjne dla Republiki Chorwacji wszedł w życie dnia 3 października 2005 r., http://ec.europa.eu/enlargement/pdf/st20004_05_hr_framedoc_en.pdf. Inne ważne wydarzenia z początku 2005 r., to m.in.: wejście w życie Porozumienia o Stabilizacji i Stowarzyszeniu (1 lutego 2005 r.), przedstawienie przez Komisję Europejską tzw. mapy drogowej (Road Map) dla Bałkanów Zachodnich, wskazującej na poszczególne etapy ich integracji z Unią Europejską.

${ }^{22}$ Pregovaračka stajališta, http://www.eu-pregovori.hr/Default.asp?ru=437\&si$\mathrm{d}=\&$ akcija=\&jezik=1. 
administracyjne ${ }^{23}$.Znalazły się wśród nich m.in.: Delegacja Państwowa Republiki Chorwacji ds. Negocjacji Akcesyjnych Republiki Chorwacji z Unią Europejska, Grupa ds. Prowadzenia Negocjacji Akcesyjnych Republiki Chorwacji z Unia Europejska, Grupy Robocze ds. Przygotowania Negocjacji w ramach poszczególnych obszarów negocjacyjnych, Sekretariat Grupy Negocjacyjnej, Narodowy Komitet ds. prowadzenia negocjacji o przystapieniu Republiki Chorwacji do Unii Europejskiej. Niezwykle istotny był w tym przypadku także wybór głównego negocjatora. Funkcję tę powierzono Vladimirowi Drobnjakowi, osobie odznaczającej się dużym profesjonalizmem, sprawnie poruszającej się po tematyce unijnej, ale nie powiązanej politycznie z żadna z chorwackich partii. Co przy tym istotne, w Republice Chorwacji, od momentu, gdy opowiedziano się za chęcią przystapienia do UE, w parlamencie panował consensus. Świadomość potrzeby zjednoczenia podobnie postrzegana była wśród wszystkich najważniejszych partii politycznych (SDP, HDZ, HNS, HSS), jak również wśród przedstawicieli mniejszości.

Negocjacje akcesyjne prowadzone były przez sześć lat - od października 2005 r. do 30 czerwca 2011 r. Ich zamknięcie zbiegło się z końcem prezydencji węgierskiej. Spośród wszystkich 35 rozdziałów negocjacyjnych, najbardziej problematyczne okazały się: nadmierna instytucjonalizacja w państwie, szerząca się i trudna do zwalczenia korupcja (sięgająca najwyższych przedstawicieli państwa), współpraca z Trybunałem w Hadze czy dwustronne relacje z sasiednia Słowenia, która w najmniej oczekiwanym dla Chorwacji momencie (grudzień 2008 r.) zablokowała na kilka miesięcy ich przebieg, opóźniając tym samym, zapowiadane na 2009 r. zamknięcie negocjacji. Wśród rozdziałów, na których zamknięcie trzeba było czekać najdłużej, znalazły się: konkurencja rynkowa (rozdział 8), sądownictwo i prawa podstawowe (rozdział 23), postanowienia finansowe i budżetowe (rozdział 33) oraz tzw. pozostałe pytania (rozdział 35).

Polityczne poparcie ze strony liderów państw i rządów dla zakończenia negocjacji akcesyjnych przez Chorwację wyrażono 24 czerwca 2011 r. ${ }^{24}$ Zamknięcia ostatnich czterech rozdziałów dokonano 30 czerwca 2011 r. w trakcie Konferencji Międzyrządowej. Referendum dotyczace przystapienia Republiki Chorwacji do Unii Europejskiej zostało przeprowadzone zgodnie z ustaleniami, tj. po 30 dniach od momentu podpisania umowy o akcesji Chorwacji do tej polityczno-gospodarczej organizacji2 ${ }^{25}$. Dnia 22 stycznia 2012 r., na pytanie „Czy jest

${ }^{23}$ Patrz: Ministarstvo Vanjskih Poslova i Evropskih Integracija Republike Hrvatske, http://www.mvpei.hr.

${ }^{24}$ Croatia: congratulations on the expected conclusion of EU accession negotiations. Joseph Daul MEP, Chairman of the EPP Group, EPP Group in the European Parliament, 24 VI 2011, http://136.173.161.106/Press/showpr.p?PRControlDocTypeID=1\&PRControIID=10457\&PRContendID=17651\&PRContentLG=en.

${ }_{25}$ Referendum o przystapieniu Chorwacji do Unii Europejskiej odbędzie się po podpisaniu umowy akcesyjnej, Aktualności, Wydział Handlowy Ambasady RP w Zagrzebiu, 29 X 2010, http://zagrzeb.trade.gov.pl/pl/aktualnosci/article/y,2010,a,12180,.html. 
Pan/Pani za członkostwem Republiki Chorwacji w Unii Europejskiej?" 66,27\% ankietowanych udzieliło pozytywnej odpowiedzi. Przeciw było 33,17\% obywateli (na wymagane $50 \%+1$ głos wszystkich osób biorących udział w głosowaniu). Frekwencja wynosiła 43,51\%, co oznacza, że w głosowaniu udział wzięło 1960208 obywateli ${ }^{26}$. Wpływ na wyniki referendum mogła mieć nie tyle kampania, prowadzona w państwie w miesiącach poprzedzających głosowanie zarówno przez rząd, opozycję, jak i sportowców, aktorów, ile oświadczenie, jakie 21 stycznia 2012 r. skierował z Hagi do chorwackich mediów gen. A. Gotovina: „Jutro w Hadze zagłosuję za wejściem do Unii Europejskiej, do której Chorwacja cywilizacyjnie i historycznie przynależy" ${ }^{\prime 2}$. Wyniki referendum nie były jednak zaskoczeniem. Sondaże poprzedzające głosowanie wskazywały, że można było spodziewać się takiego rezultatu. Dane z 26 lipca 2011 r., uzyskane przez Agencję Ipsos Puls, sugerowały, że aż 82\% spośród 943 ankietowanych, w wieku powyżej 18. roku życia, wzięłoby udział w głosowaniu. Spośród tych osób 60\% głosowałoby „za”, $33 \%$ „przeciw”, a 6\% udzieliłoby odpowiedzi „nie wiem”. Co ciekawe, miesiąc wcześniej (czerwiec 2011 r.), w badaniach przeprowadzonych na zamówienie chorwackiego Ministerstwa Spraw Zagranicznych i Integracji Europejskiej „za” chorwacka akcesją opowiadało się $57 \%$ obywateli, ,przeciw” było $37 \%$, „niezdecydowanych” zaś 7\%. Dane te wyraźnie wskazuja na pozytywny trend prounijny. Kiedy analizie podda się odpowiedzi wszystkich ankietowanych, łącznie z osobami, które nie wzięłyby udziału w referendum, „za” przystapieniem w dalszym ciągu opowiadało się więcej niż połowa badanych (52\%), „przeciw” $38 \%$, a $10 \%$ „nie miało zdania”. I w tym przypadku dane z wcześniejszego miesiąca wskazywały na poparcie $46 \%$ oraz sprzeciw $43 \%$. Niezdecydowanych było $11 \%$ (badania przeprowadzone między 1 a 20 lipca 2011 r.). Gdyby na wyniki spojrzeć pod kątem demograficznym, największe poparcie dla członkostwa Chorwacji w UE było, i jest nadal, widoczne wśród mieszkańców północnej Chorwacji (59\%), Zagrzebia i okolic (53\%), Dalmacji (53\%), Istrii i Przymorza (52\%). Przeciwnicy, to głównie osoby z terenów Liki i Banowiny (46\%) oraz Slawonii (43\%). Nie ma widocznego, wyraźnego rozdźwięku między poparciem udzielanym akcesji przez kobiety i mężczyzn, natomiast różnicuje się ono w zależności od poziomu edukacji. Osoby wykształcone, które ukończyły wyższe studia, są największymi zwolennikami integracji (63\%), podobnie osoby w przedziale wiekowym 25-34 lata (55\%) i 55-64 lata (58\%). Przeciwnikami natomiast była głównie młodzież, w wieku między 18. a 24. rokiem życia (48\%), ze średnim wykształceniem $(42 \%)^{28}$.

${ }^{26}$ Rezultati referenduma: 66,27 posto birača ZA, 33,13 posto PROTIV ulaska u EU, „Dnevnik”, http://dnevnik.hr/vijesti/hrvatska/rezultati-referenduma.html (dostęp 23 II 2012).

${ }^{27}$ General Gotovina: Ja ću glasati za, tamo civilizacijski pripadamo, „Večernji list”, http://www.vecernji.hr/vijesti/general-gotovina-ja-cu-glasati-eu-tamo-civilizacijski-pripadamo-clanak-368521 (dostęp 24 II 2012).

${ }^{28}$ HINA, Istraživanje: Raste potpora EU-u i interes za referendum, Ministarstvo Vanjskih Poslova i Evropskih Integracija Republike Hrvatske, http://www.mvpei.hr/ view1/default.asp?ru=484\&gl=201107280000002\&sid=\&jezik=1. 
Akcja informacyjna na rzecz przystapienia Chorwacji do UE była prowadzona przez kilka lat. Można mówić o różnym stopniu jej powodzenia. Mniej więcej od początku 2011 r. zyskała ona jednak na intensywności. Władze poświęciły na ten cel więcej funduszy i zaangażowania. $\mathrm{Z}$ wywiadów, udzielanych przez przedstawicieli Ministerstwa Spraw Zagranicznych i Integracji Europejskiej wynika, że im bliżej było do referendum, tym nasilenie akcji rosło. Opracowana w tym celu Strategia Komunikacyjna obejmowała m.in.: emisję programów informacyjnych o Unii w chorwackim radiu i telewizji (zarówno lokalnej, jak i regionalnej), spotkania w różnych częściach państwa z przedstawicielami chorwackich ministerstw, jak i znanymi politykami, sportowcami, aktorami, którzy od lat cieszą się popularnością wśród Chorwatów (szczególna uwaga poświęcona została spotkaniom w rejonach słabo rozwiniętych gospodarczo, gdzie poparcie dla UE było niskie). Uwzględniono publikacje książek, informatorów, ulotek pokazujących korzyści wynikające z przystapienia do Unii. Popularnościa cieszyły się spotkania ze studentami, uczniami szkół podstawowych i średnich. Dla zainteresowanych uruchomiona została także bezpłatna infolinia „HALO EU”, dostępna całą dobę. Dzwoniąc pod numer 0800622622 uzyskać można było odpowiedzi na wszelkie nurtujące pytania związane z członkostwem Chorwacji w Unii Europejskiej ${ }^{29}$.

Pomoc finansowa udzielana Chorwacji w ramach przedakcesyjnych funduszy może być potwierdzeniem zaangażowania i zainteresowania regionem Bałkanów Zachodnich ze strony UE. Szacuje się, że dzięki dotacjom władze z Zagrzebia do 2013 r. zyskają około 800 mln euro. W projekcie Komisji Europejskiej, zakładającym, że państwo to, z dniem 1 lipca 2013 r. stanie się pełnoprawnym członkiem Unii, podaje się do wiadomości, że w samym drugim półroczu 2013 r. zyska ono do dyspozycji środki finansowe, w ramach unijnych funduszy pomocowych, w wysokości 687,5 mln euro. Z kwoty tej 496,8 mln euro ma zostać przeznaczone na zrównoważony rozwój, z czego 449,4 mln euro na realizację projektów majacych przyczynić się do rozwoju gospodarczego i wzrostu zatrudnienia, a 47,4 mln euro na poprawę konkurencyjności wzrostu gospodarczego i zatrudnienia. Środki skierowane na gospodarowanie bogactwami narodowymi wyniosa 20,4 mln euro (9 mln na finansowanie inwestycji rynkowych, 8,7 mln euro na Europejski Fundusz Rybołówstwa, 2,7 mln euro na wsparcie ochrony środowiska). 73,3 mln euro wpłynie na rzecz obywatelstwa, wolności, bezpieczeństwa i wymiaru sprawiedliwości. Poczynione zostaną kroki w celu wprowadzenia Chorwacji do strefy Schengen. Na chorwacka administracje przewidziano $22 \mathrm{mln}$ euro ${ }^{30}$. Pomoc finansowa dla Republiki Chorwacji ze strony Unii Europejskiej, w rzeczywistości zaczęła się znacznie wcześniej. Warto zwrócić tu uwagę na fakt, że od

${ }^{29}$ Halo EU, Ministarstvo Vanjskih Poslova i Evropskih Integracija Republike Hrvatske, http://www.mvpei.hr.

${ }^{30}$ Fundusze UE dla Chorwacji od połowy 2013 roku, ,Jutarnilist.hr”, http://zagrzeb. trade.gov.pl/pl/aktualnosci/article/a,17571,.html. 
początku lat 90. XX w., to zniszczone wojną domową państwo, dzięki pomocy humanitarnej udzielonej mu właśnie przez kraje Wspólnoty, mogło ponownie zaistnieć na arenie międzynarodowej. Do $2000 \mathrm{r}$. UE, zgodnie z rozporządzeniem Rady nr 1628/96 z dnia 25 lipca 1996 r., poza pomocą kierowaną do obywateli chorwackich, przekazywała również środki finansowe, mające wspomóc i ułatwić powrót uchodźców i osób wypędzonych na terytorium Chorwacji. Dzięki programowi OBNOVA starano się pomóc przy odbudowie zniszczonych w trakcie wojny domów, jak również wpłynąć na rekonstrukcję gospodarki ${ }^{31}$. W 2000 r. Chorwacja przyjęła nowy program pomocy finansowej CARDS, który zastapił wcześniejszy program OBNOVA. CARDS, jako Program pomocy technicznej i finansowej dla państw Bałkanów Zachodnich (Community Assistance for Reconstruction, Development and Stabilization) został uruchomiony Dyrektywa Rady nr 2666/2000 i przewidziany na sześć lat. Miał służyć jako instrument wsparcia i przyczyniać się do sprawniejszego przeprowadzania Porozumienia o Stabilizacji i Stowarzyszeniu. Od chwili, gdy Chorwacja w czerwcu 2004 r. otrzymała status państwa kandydata do Unii, skierowano w stosunku do niej przedwstępną strategię umożliwiająca korzystanie z takich funduszy pomocy przedakcesyjnej, jak PHARE, ISPA i SAPARD. Programy, określane mianem funduszy pierwszej generacji, miały za zadanie pobudzenie państwa do przeprowadzania istotnych politycznych, gospodarczych, socjalnych i instytucjonalnych reform. Fundusze przedakcesyjne, wraz z programem CARDS, dawały Chorwacji wsparcie, przyczyniające się do stopniowej integracji z Unią Europejską. Kiedy w 2007 r. weszła w życie nowa perspektywa finansowa, Komisja Europejska opracowała nowy instrument pomocowy dla krajów kandydujących do UE, tzw. Instrument Pomocy Przedakcesyjnej IPA (Instrument for Pre-Accession Assistance). IPA zastapił funkcjonujące w latach 2000-2006 fundusze pomocowe (PHARE, ISPA, SAPARD) i instrument finansowy programu CARDS dla Bałkanów Zachodnich ${ }^{32}$. Po przystapieniu do Unii Europejskiej Chorwacja w dalszym ciagu będzie mogła korzystać ze środków przedakcesyjnych IPA na realizację projektów rozpoczętych przed uzyskaniem członkostwa w UE. Środkami tymi będą zarządzały właściwe chorwackie agencje. Środki z funduszy przedakcesyjnych na pokrycie kosztów administracyjnych będzie można wykorzystywać $\mathrm{w}$ terminie do dwóch lat od daty przystapienia Chorwacji do UE, a na cele rewizji realizacji projektów finansowanych z tych środków nawet do pięciu lat od daty akcesji do Uniï ${ }^{33}$.

${ }^{31}$ Program OBNOVA - program Unii Europejskiej na rzecz odbudowy skierowany do Bośni i Hercegowiny, Chorwacji, Federacyjnej Republiki Jugosławii i FYROM (Byłej Jugosłowiańskiej Republiki Macedonii). Po 2000 r. zastapiony przez CARDS. Unia Europejska, Glosariusz Europy i Unii Europejskiej, ,psz.pl”, http://www.psz.pl/component/ option,com_glossary/Itemid,187/catid,171/func,view/term,Obnova/.

${ }^{32}$ IPA - pomoc przedakcesyjna dla krajów Batkanów Zachodnich, ,„portfel.pl”, http:// www.portfel.pl/pdf/art2834.

${ }^{33}$ Fundusze UE dla Chorwacji... 
Chorwacja, dążąc do członkostwa w Unii Europejskiej, nie pozostaje obojętna na współpracę dwustronna. Korzysta z doświadczeń państw będących członkami Wspólnoty i stara się inicjować spotkania ze specjalistami z różnych dziedzin. W trakcie polskiej prezydencji w UE dało się zauważyć, że strona polska odgrywała w stosunku do Chorwacji istotną rolę ${ }^{34}$. Pomimo że dotychczasowe kontakty ograniczały się głównie do utrzymania dobrych stosunków pomiędzy państwami, reprezentowanymi przez ambasadora Republiki Chorwacji w Rzeczypospolitej Polskiej Ivana Del Vechio i ambasadora Rzeczypospolitej Polskiej w Republice Chorwackiej Wiesława Tarkę, to od pewnego czasu można mówić o ich intensyfikacji. Kalendarz polsko-chorwackich spotkań nigdy nie był tak wypełniony, jak w latach 2010-2011. Obfitował w liczne wizyty i spotkania zarówno na szczeblu oficjalnym, jak i prywatnym. 18 lutego 2010 r. polski prezydent Lech Kaczyński wraz z małżonką wzięli udział w inauguracji przejęcia władzy w Zagrzebiu przez nowego prezydenta Chorwacji - Ivo Josipovicia. W maju 2011 r. polski premier Donald Tusk złożył wizytę chorwackiej premier Jadrance Kosor, zobowiązując się do pomocy, o ile zajdzie taka potrzeba. Podczas kolejnej wizyty, w lipcu 2011 r., premierzy podali do wiadomości opinii publicznej, że końcowy tekst chorwackiej umowy akcesyjnej znajduje się w trakcie opracowania $^{35}$. Jego uroczyste podpisanie nastapiło w Brukseli dnia 9 grudnia $2012 \mathrm{r}$. Minister sprawiedliwości Krzysztof Kwiatkowski, na zaproszenie chorwackiego ministra sprawiedliwości Ivana Šimonovicia, przebywał w Zagrzebiu w dniach 16-17 czerwca 2010 r. z wizytą oficjalna. Spotkał się on również z prokuratorem generalnym Republiki Chorwacji Mladenem Bajiciem oraz prezesem tamtejszego Sądu Najwyższego Branko Hrvatinem. Była to trzecia wizyta i spotkanie przedstawicieli resortów sprawiedliwości Polski i Chorwacji w ciągu roku, poświęcone m.in. funkcjonowaniu wymiaru sprawiedliwości i zagadnieniom odnoszącym się do przygotowań Chorwacji do członkostwa w Unii. W trakcie wizyt, istotnych również dla Polski, która od 1 lipca 2011 r. obejmowała prezydencję w Unii Europejskiej, rozważano skutki przystapienia Chorwacji do Wspólnoty. Analizowano funkcjonowanie tamtejszego wymiaru sprawiedliwości, głównie w kontekście przeprowadzanej reformy systemu probacji i egzekucji orzeczeń i wyboru sędziów oraz prokuratorów ${ }^{36}$. Okazją do spotkania w Polsce prezydenta Zagrzebia Milana Bandicia i prezydent Warszawy Hanny Gronkiewicz-Waltz, stały się obchody Święta Narodowego Republiki Chorwacji. Przygotowano i podpisano

${ }^{34}$ Stosunki dyplomatyczne pomiędzy państwami nawiązane zostały 18 kwietnia $1992 \mathrm{r}$.

35 Podpisanie traktatu akcesyjnego najprawdopodobniej będzie miało miejsce $w$ Warszawie, News, MVP HR, http://pl.mfa.hr/?mv=2397\&mh=404 (dostęp 20 VII 2011).

${ }^{36}$ Minister Sprawiedliwości Krzysztof Kwiatkowski z wizyta w Chorwacji, Ministerstwo Sprawiedliwości, http://ms.gov.pl/pl/archiwum-informacji/news,1842,10,minister-sprawiedliwosci-krzysztof-kwiatkowski-z.html (dostęp 17 VI 2010). 
umowę o współpracy między Warszawą a Zagrzebiem. Również i przy tej okazji podkreślano znaczenie miejsca i chwili, w jakich doszło do rozmów ${ }^{37}$. Współpraca, której korzenie sięgają lat 90., służyć ma głównie wymianie doświadczeń. Wcześniej polegała ona m.in. na odrestaurowywaniu przez polskich konserwatorów zniszczonych w trakcie wojny domowej zabytków, dziś przede wszystkim skupia się na fachowej pomocy w zakresie pozyskiwania funduszy europejskich. Przede wszystkim tych przeznaczonych na projekty zwiazane z miejską infrastrukturą komunalna, komunikacją miejska, ekologia, kulturą i rozwojem sportu ${ }^{38}$. Dla Chorwacji polskie osiagnięcia i doświadczenia, związane z ubieganiem się o pieniądze unijne, sa przykładem godnym naśladowania. Znaczacy głos w Chorwacji należał w 2011 r. do szefowej Ministerstwa Rozwoju Regionalnego Elżbiety Bieńkowskiej ${ }^{39}$ i wicepremiera Waldemara Pawlaka (do spotkań doszło w Zagrzebiu 16 lutego 2011 r. oraz w trakcie Croatia Summit, odbywającego się w połowie lipca 2011 r. $)^{40}$. Można przypuszczać, że do kolejnych spotkań dojdzie w Brukseli. Wstępując do Unii Europejskiej Chorwacja zyska w Parlamencie Europejskim 12 miejsc dla swoich posłów i 1 miejsce dla przedstawiciela w Komisji Europejskiej oraz miejsca w innych organach unijnych. Mimo zbliżającego się sukcesu, przed Chorwacja jeszcze wiele pracy. Niezbędne są dalsze reformy, których monitorowanie trwać będzie do 1 lipca 2013 r. Zaangażowanie państwa $\mathrm{w}$ proces przemian jest bardzo istotne. Wielokrotnie o Chorwacji mówi się, że może być ona przykładem dla pozostałych państw byłej Jugosławii. Szczególnie, gdy weźmiemy pod uwagę fakt, że o członkostwo we Wspólnocie ubiegają się kolejne kraje Bałkanów Zachodnich. Zadaniem Chorwacji, jako pełnoprawnego członka Unii, będzie udzielanie im pomocy i dbanie o dobre stosunki w regionie, które przyczynią się do postrzegania go jako bardziej stabilnego, zachęcającego do rozwoju turystyki i współpracy gospodarczej.

${ }^{37}$ Dla Polski był to czas przygotowań do prezydencji, dla Chorwacji okres zakończenia negocjacji z UE.

38 Spotkanie Milana Bandića i Hanny Gronkiewicz-Waltz, 20 VI 2011, http://pl.mfa. hr/InfoPopup.aspx?mv=2397\&pr=t\&id=12808.

39 PAP, Chorwacja skorzysta z naszych doświadczeń $w$ sprawie funduszy unijnych, „onet.pl”, $\quad$ http://biznes.onet.pl/mrr-chorwacja-skorzysta-z-naszych-doswiadczen-ws-f,18491,4047067,1,news-detal (dostęp 10 XII 2010).

${ }^{40}$ W. Krzyczkowski, Chorwacja ma szansę szybko wejść do UE, „gość.pl”, 9 VII 2011, http://gosc.pl/doc/899493.Chorwacja-ma-szanse-szybko-wejsc-do-UE. 